\title{
Congenital Dislocation of Knee
}
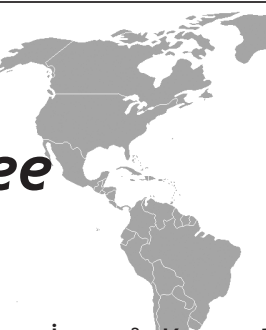

Mehmet Elmadağ ${ }^{1}$, Hasan Hüseyin Ceylan ${ }^{1}$, Mehmet Erdil ${ }^{1}$, Yunus İmren ${ }^{2}$, Kerem Bilsel ${ }^{1}$, İbrahim Tuncay ${ }^{1}$

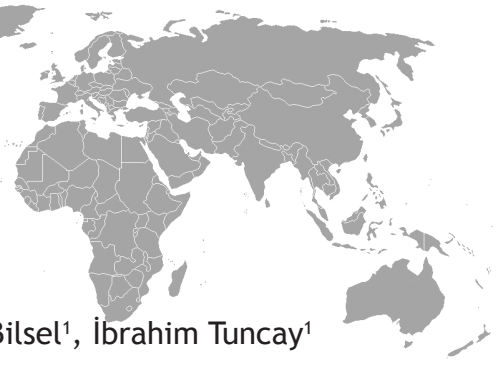

ABSTRACT

Congenital dislocation of knee is a rare entity in clinical practice. A three-day-old newborn was admitted to hospital by his parents, with complaint of the abnormal position and hyperextension posture of his left knee. Several conservative and surgical methods have been described for treatment of this rare congenital knee instability.

Key words: Congenital knee dislocation, knee luxation, congenital deformity

\section{Konjenital Diz Dislokasyonu}

ÖZET

Konjanital diz dislokasyonu klinik pratikte nadir bir durumdur. Üç günlük erkek yenidoğan sol dizinde anormal pozisyon ve hiperekstansiyon șikayeti ile hastaneye getirildi. Konjenital diz dsilokasyonu için çeșitli konservatif ve cerrahi metodlar bildirilmiștir

Anahtar kelimeler: Diz dislokasyonu, diz luksasyonu, doğuștan deformite

\section{INTRODUCTION}

Congenital dislocation of knee is a rare entity in clinical practice. Estimated incidence is nearly 0.017 in 1000 live births (1). This deformity generally accompanies with other congenital musculoskeletal abnormalities like developmental hip dysplasia, club foot, spina bifida, arthrogryposis multiplex congenita, hindfoot and forefoot deformities (2-4). Shortened quadriceps femoris muscle is determined to be the main underlying pathology (3). Several conservative and surgical methods have been described for treatment of this rare congenital knee instability.

\section{CASE}

A three-day-old newborn was admitted to hospital by his parents, with complaint of the abnormal position

${ }^{1}$ Bezmialem Vakıf University Medical Faculty Hospital, Orthopaedics and Traumatology Department. Fatih/Istanbul/Turkey, ${ }^{2}$ Kars State Hospital, Orthopaedics and Traumatology Clinic. Kars/Turkey

Received: 22.05.2012, Accepted: 31.05.2012 and hyperextension posture of his left knee. (Figure 1) He was born by spontaneous vaginal delivery. His birth weight was 3150 grams with a gestational age of 39 weeks. The left knee of the baby was relatively instable in all directions and it was impossible to bend the knee. 35 degrees of hyperextension and 10 degrees of passive flexion were detected at his left knee. Grade 3 congenital knee dislocation was diagnosed by physical examination and radiologic studies. Any other concomitant deformities were not detected in musculoskeletal examination. The hip ultrasonography was normal. After informed consent of the parents, we initially applied manipulation and closed reduction with serial plaster casts for two weeks. The cast was changed every two weeks under sedation anesthesia. Initial reduction was not achieved by serial closed reduction and casting. The flexion was increased with each cast, but persistence of the deformity was seen within 10 weeks of the initial

Correspondence: Hasan Hüseyin Ceylan, MD,

Bezmialem Vakif Univ. Adnan Menderes Bulv. Ortopedi Serv. Kat 2. 34093 Fatih / Istanbul / Turkey

Tel: +902124531700/+905306966045

E-Mail:drhhc@yahoo.com 


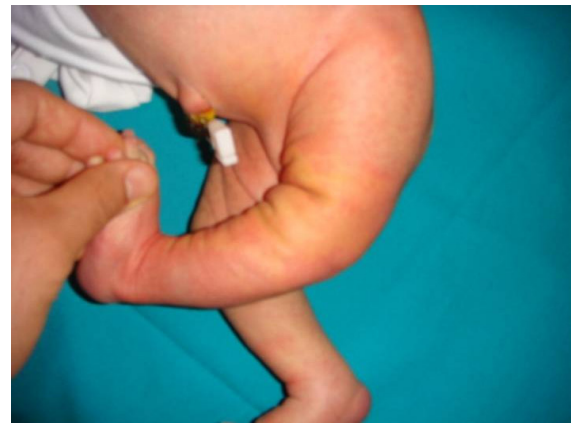

Figure 1. Hyperextension posture of the left knee

conservative treatment. Closed reduction with percutaneous quadricepsplasty of the knee joint was carried out as Roy and Crawford described (5). The whole extremity was held in above knee cast in 70 degrees of flexion for six weeks after operation. The accurate reduction was encountered by radiographic evaluation (Figure 2). The cast was removed and active range of motion was encouraged after six weeks. Active assisted knee exercises were started and parents were attended for continuous physiotherapy for maintenance of the joint reduction. Optimal strength and range of motion were achieved in six months follow-up period when compared with the contralateral healthy knee (Figure 3). Any signs of instability and extensor lag were not detected. The range of flexion was nearly 140 degrees and the extension was 0 degree. The physical examination of the knee was painless and comfortable after one year follow up, and no residual instability detected. The boy is two years-old and can stand and walk without external support now.

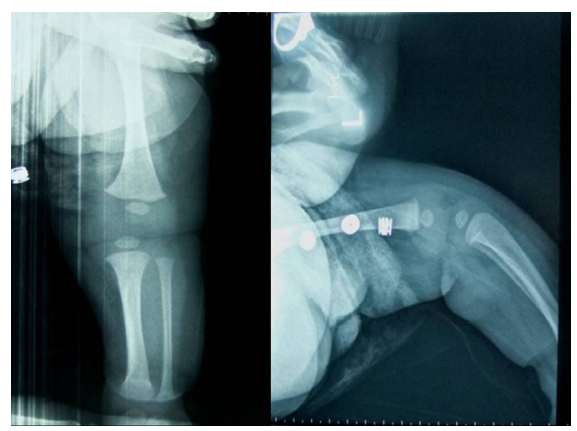

Figure 2. Postoperative $x$-ray examination for controling reduction

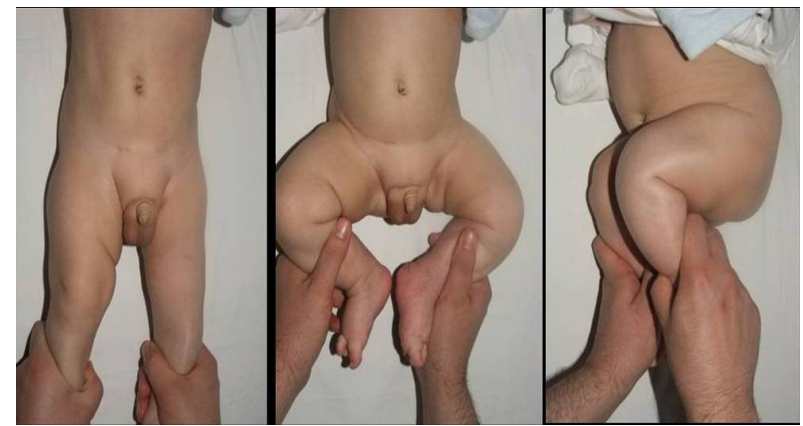

Figure 3. The operated knee has same range of motion with right one at six months follow-up

\section{DISCUSSION}

Congenital knee dislocation is first described by Chanssier in 1812 (6). Reported incidence is nearly 0.017 in 1000 live births without any difference between right and left knees (7). Main etiologic factor is not known yet. Three different theories have been described about this rare entity. According to mechanical theory, the deformity is originating from abnormal fetal posture in intrauterine period of life (6-8). Another and most reliable theory is the primary embryologic theory that easily explains the other additional deformities accompanying with the knee problem (9). The fibrotic quadriceps muscle is accepted as a mesenchymal defect and explains the third mesenchymal theory (6-8).

Leveuf and Pais classification is the most popular classification and categorizes the deformity into three subgroups (10). Grade 1 is the most common type and not a true dislocation and accepted as congenital hyperextension. Nearly 15 to 20 degrees of hyperextension can be detected and passive range of flexion is maximum 90 degrees. At Grade 2, congenital subluxation with joint incongruency is seen. Passive flexion of the knee is impossible and 25 to 40 degrees of hyperextension can be achieved. At Grade 3 cases there is no contact between the joint surfaces of tibia and femur. Proximal tibial epiphysis is located anterior to femoral condyles. Our case was Grade 3 congenital knee dislocation according to Leveuf classification. The rate of accompanying musculoskeletal deformity is estimated to be nearly 82 $88 \%$ in multiple reports. Additional congenital problems may include developmental hip dysplasia, foot deformities, cleft lip, Down syndrome, hydrocephaly, spina bifida, imperforated anus, congenital elbow luxation, 
Larsen syndrome, arthrogryposis multiplex congenita, Ehler-Danlos syndrome, myelomeningocele and Turner syndrome that must be ruled out before accurate treatment of knee $(6,7,11,12)$. Systemic renal and cardiac problems should also be evaluated. In our case, physical examination and all parameters were normal and the deformity was localized only at knee joint. We only treated the knee luxation as discussed in literature. (8)

Prenatal diagnosis of congenital knee dislocation is possible with ultrasonographic examination $(6,10)$. The gynecologist or pediatrician can easily diagnose this anomaly with a physical examination of the newborn. While examining the hip, the range of motion in both knees must be controlled and hyperextension must be ruled out. In suspicious cases, direct radiologic examination with lateral view of knee can be helpful. Distal part of the knee joint (proximal tibia) is located at anterior to proximal part (distal femur) at lateral view $(6,10)$.

Serial manipulation and casting is recommended initially in newborns $(6-8,11,13)$. Casting should be done in full flexion position as knee allows. Forced flexion is not advised because of potential problems like fracture, epiphyseal damage and impaired circulation (1). Cast should be changed in every two weeks until the accurate reduction is achieved. Several surgical procedures are described in literature. It's not easy to dissect the newborn knee and apply complicated surgeries because of immature structures. To achieve normal flexion gap, many surgeons apply quadricepsplasty. Extensor lag, which is one of the major complications that can be seen after quadricepsplasty, can be defined as an inability to achieve normal active extension of knee joint. We applied the percutaneous technique for reduction. This method is less harmful and minimally invasive. The approach we applied in this case was introduced by Roy and Crawford, this method targets the percutaneous recession of the quadriceps mechanism and release of the fascia over the rectus femoris and the medial and lateral retinaculum (5).

The advantage of this approach is the avoidance of the scar tissue and other complications related with extensive surgery. Physicians should know about this rare congenital deformity. In case of neglected knee luxations, arthrodesis is another recommended way for pain management. Further knee instability and decreased range of motion is the main problem at following years after congenital knee luxation surgery (7).
Family should be informed about further problems like early arthrosis or potential knee problems in the future. The incidence is very rare (17 in million live births only) but early diagnosis of this deformity is very important for effective treatment and avoids further medico-legal problems (1).

\section{REFERENCES}

1. Jacobson K, Vopalecky F. Congenital dislocation of the knee. Acta Orthop Scand 1985;56:1-7

2. Curtis BH, Fisher RL. Congenital hyperextension with anterior subluxation of the knee surgical treatment and long term observations. J Bone Joint Surg Am 1969;51A:255-9

3. Katz MP, Grogono BJS, Soper KC. The etiology and treatment of congenital dislocation of knee. J Bone Joint Surg $\mathrm{Br}$ 1967;49B:112-20

4. Dobbs MB, Boehm S, Grange DK, Gurnett CA. Case report: congenital knee dislocation in a patient with Larsen syndrome and a novel filamin B mutation. Clin Orthop Relat Res 2008;466(6):1503-9

5. Roy DR, Crawford AH. Percutaneous quadriceps recession: a technique for management of congenital hyperextension deformities of the knee in the neonate. J Pediatr Orthop 1989;9:717-9.

6. Tachdjian MO: Pediatric Orthopaedics. Volume 1. Philadelphia. Saunders 1990: 609-18

7. Warner WC, Canale ST, Beaty JH: Congenital deformities of the knee. Volume 2, In Insall JN, Scott WN (eds): Surgery of the Knee. Philadelphia. Churchill Livingstone 2001:1337-56

8. Johnson E, Audell R, Oppenheim WL. Congenital dislocation of the knee. J Pediatr Orthop 1987;7(2):194-200

9. Fernandez-Palazzi F, Silva JR. Congenital dislocation of the knee. Int Orthop 1990;14(1):17-9

10. Rössig S., Lazovic D., Rühmann O. [Ultrasound imaging of congenital knee joint dislocation. Value in diagnosis and therapy]. [Article in German]. Ultraschall Med 1998; 19(5): 234-40.

11. Beaty JH: Congenital anomalies of lower extremity. Volume 1, In Canale ST (ed): Operative Orthopaedics. St.Louis. Mosby 1998:925-1021

12. Roach JW, Richards BS. Congenital dislocation of the knee. J Pediatr Orthop 1988;8(2):226-9

13. Ferris $B$, Aichroth $P$. The treatment of congenital knee dislocation. A review of nineteen knees. Clin Orthop Relat Res 1987;(216):135-40 